\title{
The citizen-makers: Ethical dilemmas in immigrant integration
}

\author{
Liav Orgad* (1)
}

\begin{abstract}
The topic of citizen-making-turning migrants into citizens-is one of the most politically contested policy areas in Europe. Access to European citizenship is governed by national law with almost no EU regulation. The Article brings to the fore normative concerns associated with citizen-making policies in Europe (Section 2). It examines ethical dilemmas involved in the process of creating new citizens (Section 3) and promotes the adoption of a European legal framework on access to citizenship (Section 4). The overall claim is that every newcomer will be required to demonstrate, as a prerequisite for citizenship, attachments to the constitution of the specific Member State, yet the test will be functional, flexible and non-exclusive. As the topic of EU citizenship law is currently at the centre of the European agenda, this article has both theoretical significance and policy implications.
\end{abstract}

\section{1 | INTRODUCTION}

As a mortar is made by a mortar-maker, so a citizen is made by a citizen-maker.-Aristotle ${ }^{1}$

The manner in which new citizens are created is one of the most fundamental questions in law and political theory. At stake, as Ayelet Shachar notes, "is the regulation of the most important and sensitive decision that any

*Director, "Global Citizenship Governance", Robert Schuman Centre for Advanced Studies, European University Institute; Head, "International Citizenship Law", WZB Berlin Social Science Center; Associate Professor, Lauder School of Government, Interdisciplinary Center (IDC) Herzliya. Earlier versions of the article were presented at the Center for Global Constitutionalism, WZB Berlin; the Munk School of Global Affairs, University of Toronto; and the Edmond J. Safra Center for Ethics, Harvard University. I am grateful to the discussants-Ayaan Hirsi Ali, Noah Feldman and Frances Kamm-and participants for their valuable feedback. Thanks are also due to Ana Maria Corrêa and Fabienne Bretscher for excellent research assistance; Emilien Fargues, Monique Foudraine, Kristine Görgen, Johanna Hase, Ashley Mantha Hollands, Christian Joppke and Shelly Simana for helpful suggestions; and two anonymous reviewers whose constructive comments have significantly improved the article. This study is supported by the European Research Council Starting Grant (\# 716350).

${ }^{1}$ Aristotle, Politics: A Treatise on Government, Book III, Ch. II (W. Ellis trans., Book Jungle, 2007).

${ }^{2}$ A. Shachar, 'Dangerous Liaisons: Money and Citizenship', in A. Shachar and R. Bauböck (eds.), Should Citizenship be for Sale? (EUI Working Paper RSCAS 2014/01, European University Institute, 2014), at 3.

This is an open access article under the terms of the Creative Commons Attribution-NonCommercial License, which permits use, distribution and reproduction in any medium, provided the original work is properly cited and is not used for commercial purposes. (c) 2019 The Authors. European Law Journal published by John Wiley \& Sons Ltd. 
political community faces: how to define who belongs, or ought to belong, within its circle of members". ${ }^{2}$ The law of naturalisation functions as the gatekeeper-it is designed to include the desirable people and exclude the undesirable ones. In so doing, it provides a unique platform to reflect on three issues: (1) defining the "We"-who "we" are and what kind of community "we" want to be; (2) setting criteria for identifying the desired "They"-who is, in the state's view, an "ideal citizen", and the current understanding of what it means to become a citizen; and (3) finding "the core" to which "they" should subscribe in order to become part of the "we".

The last decade has witnessed the largest number of citizenship applications in European history and Member States face a common dilemma-whom to admit: how many, according to what criteria, and under which procedures? These questions are likely to become more acute given the rapidly growing number of newcomers to Europe, the perceived integration problems in Europe, and the divergence of policies among Member States.

This article examines the ways by which new citizens are created in Europe and analyses ethical dilemmas associated with this process. Section 2 is empirical: it describes citizen-making policies ${ }^{3}$ in Europe-a hotspot of the dilemmas associated with immigrant integration-and reveals what it means to become a citizen in the juridical sense. The legal focus is useful because the law presents the official stance of who ought to be a citizen and the formal way that "good citizenship" is perceived. Section 2 does not provide a systematic review of how to become a citizen in Europe, ${ }^{4}$ but a non-random overview of policies in three states-Denmark, Spain and Switzerland-which, although are limited examples, ${ }^{5}$ provide a diverse and wide spectrum of dilemmas involved in "citizen-making policies". Section 3 is normative: it explores ethical dilemmas related to immigrants' motivation, knowledge acquisition, belief formation and legal acceptance. The purpose is not to offer a concrete recipe for one "correct" integration policy that should apply in Europe, but to identify the central questions, competing normative interests, and alternative tradeoffs for policy-makers. Section 4 is legal: it offers a normative framework-attachments to the principles of the constitution-that can guide European states in designing immigrant integration programs and, as a later possible development, be the basis for a common EU Directive on that topic. Overall, the article seeks to theorise the field of naturalisation law and advance the adoption of an EU Directive on access to citizenship that will govern, inter alia, immigrant integration. The Europeanisation of naturalisation policies can promote not only human rights of noncitizens, but also national interests of Member States. It can set up three principal issues: states can agree on common rules, as a minimum, on issues in which there is a shared core European interest; agree to disagree on other issues, leaving them to sovereign powers; and agree on procedures that should be followed on certain issues, so that a substantive outcome will be respected when certain procedures are taken. It does not mean a uniform EU policy, but a partial harmonisation of citizenship acquisition in Europe.

\section{2 | CREATING CITIZENS}

The film "The Swissmakers" (Die Schweizermacher) tells the story of becoming a Swiss citizen. To become Swiss, a person should be politically neutral, stone sober, clean and tidy, hard-working and reliable. The officer of the

\footnotetext{
${ }^{2}$ A. Shachar, 'Dangerous Liaisons: Money and Citizenship', in A. Shachar and R. Bauböck (eds.), Should Citizenship be for Sale? (EUI Working Paper RSCAS 2014/01, European University Institute, 2014), at 3.

${ }^{3}$ There is an overlap between "citizen-making" policies and naturalisation policies, whose main goal is to make citizens out of immigrants; still, "citizen-making" may start before admission (integration from abroad) or end after a naturalisation ceremony. In addition, citizen-making policies are slightly broader than naturalisation policies because, from the perspective of states, the regulation of territorial admission pre-selects those who later may become citizens (especially in states that apply a principle of jus soli, place of birth).

${ }^{4}$ For a more systematic overview, see, e.g., R. Bauböck, E. Ersbøll, K. Groenendijk, and H. Waldrauch (eds.), Acquisition and Loss of Nationality. Volume 2: Country Analyses: Policies and Trends in 15 European Countries (Amsterdam University Press, 2006); S.W. Goodman, Immigration and Membership Politics in Western Europe (Cambridge University Press, 2014); and the GLOBALCIT database, European University Institute, at http://globalcit.eu/databases/.

${ }^{5}$ Switzerland, which is not an EU Member State, is chosen due to its unique citizen-making policy and its relevancy for Section 4 (the "attachment requirement"). The Swiss case is particularly appealing because it fits the article's claim for a core EU citizenship policy, to be upgraded by Member States (the Federal Swiss Constitution defines core requirements that are subject to further "local" amendments by the cantons and municipalities). Denmark is chosen due to its strict and heavily-regulated citizenship-making policy. Spain is chosen due to its recently-adopted citizenship test, which is less known compared to citizenship tests in other Member States. All countries face similar dilemmas of immigrant integration and have historically developed in different directions.
} 
Bureau of Naturalisation closely watches candidates at work and while driving, talks to their boss and neighbours, examines how they spend their spare time, and stops by for unexpected visits. In one scene, the Bureau officer suddenly arrives in the apartment of an Italian man, who is married to a Swiss woman. The officer is satisfied by the clean living-room, the pictures of Swiss heroes hanging on the wall, and the fact that the Italian candidate has absorbed some Swiss customs-he waves the Swiss flag, uses pedestrian crossings, chooses the right colour for rubbish bags, does not hang washing out the window, and does not drop cigarette stubs on the ground. And yet, the Bureau officer is displeased that the person "still eats pasta every day". The film is a parody of Swiss naturalisation in the 1970s; still, law and practice have remained mainly untouched: funny at best and absurd at worst.

Becoming a Swiss citizen requires meeting the admission conditions for entry into Switzerland, followed by naturalisation requirements on three levels: federal, cantonal and municipal. ${ }^{6}$ The Federal law prescribes minimum requirements. For regular naturalisation, a person must reside in Switzerland for at least ten years and demonstrate successful integration. ${ }^{7}$ The person should respect the values of the Federal Constitution, participate in the economic, social and cultural life of the society, be familiar with the Swiss ways of life, and master the national language. ${ }^{8}$ The cantons and the municipalities can add additional requirements. Thus, for instance, some municipalities demand membership in local associations, contacts with local residents, and active participation in municipal events. In order to assess the level of integration, employers and neighbours are often consulted; in some cases, even school authorities are consulted. ${ }^{9}$ Swiss municipalities "look for genuine internalisation of local customs and habits, something that can only be learned through socialisation". ${ }^{10}$ In some cases, there is a vote on each case at the municipal assembly. This reality leads to arbitrary decisions and discriminatory practice. ${ }^{11}$ Local actors have a different understanding of "good citizenship" and make their decisions accordingly. ${ }^{12}$ There are no fixed criteria and the municipalities often focus on lifestyles and political views. ${ }^{13}$

The case of Funda Yilmaz is an example. Yilmaz was born in Switzerland to parents of Turkish descent and has lived in Switzerland her entire life. She is engaged to a natural-born citizen, speaks fluent Swiss-German, and considers Switzerland her homeland. Yilmaz is an active member of local associations and, in her leisure time, likes spending time in nature and playing football. She dresses like other women of her age and does not practise any religion. At the age of 24, Yilmaz applied for Swiss citizenship (Switzerland does not grant citizenship by the principle of jus soli). She did everything necessary to become a citizen and received a perfect score (100) in a written citizenship test; and yet, her application was rejected. According to the municipality of Buchs-in the Canton of Aargau, where she works-Yilmaz has not sufficiently integrated in Switzerland. This conclusion was based on an interview with local councillors in which Yilmaz did not provide satisfactory answers to 92 questions about her way of life. Sample questions included: "Why do you want to become Swiss?" ("I was born here", she responded); "Do you celebrate the Swiss National Day?" (she does); "What would you say is typically Swiss?" ("the Alps and Toblerone"); and "Do you go on vacation in Switzerland, where, and with whom?" (she often travels with her fiancé in the Swiss lakes). In addition, Yilmaz had to clarify her views on the Turkish President Erdoğan ("he is becoming a dictator") and whether her parents

\footnotetext{
${ }^{6}$ Arts 3-5, 53-55, Ausländer- und Integrationsgesetz, AIG, SR 142.20 (2005).

${ }^{7}$ Arts 12, 14, 15a, Bürgerrechtsgesetz, BüG, SR 141.0 (2013).

${ }^{8} \mathrm{Ibid}$. See, also, arts 2-9, Bürgerrechtsverordnung, BüV, SR. 141.01 (2016) (entered into force in 2018).

${ }^{9}$ See, e.g., the judgment of Bundesgericht of 2 July 2008, BGer 1D_17/2007/daa; the judgment of Verwaltungsgerichts 2 Kammer of 21 August 2013, AGVE2013-43 (WBE.2013.136).

${ }^{10}$ A. Achermann, C. Achermann, G. D'Amato, M. Kamm and B. von Rütte, 'Country Report: Switzerland', (2013) EUDO Citizenship Observatory, 12-13 (European University Institute).

${ }^{11}$ J. Hainmueller and D. Hangartner, 'Who Gets a Swiss Passport? A Natural Experiment in Immigrant Discrimination' (2013) 107 American Political Science Review, 159.

${ }^{12} \mathrm{M}$. Helbling, 'Switzerland: Contentious Citizenship Attribution in a Federal State' (2010) 36 Journal of Ethnic and Migration Studies, $793,794$.

${ }^{13}$ 'Étude sur la Procédure de Naturalisation dans le Canton de Friboug', Commission pour l'Intégration des Migrant-e-s et la Prévention du Racisme (Fribourg, 2013).
} 
accept her spouse although he is not Turkish ("they love him"), as well as to explain whether she likes hiking (no, she prefers snowboarding) and what kind of fitness training she does ("pole dancing"). ${ }^{14}$

Following two interviews, the Buchs council found that Yilmaz did not demonstrate successful integration as required by law. ${ }^{15}$ She was unfamiliar with the living conditions in Switzerland and did not have sufficient knowledge of the social and cultural life or understanding of Swiss peculiarities. The town council praised her excellent performance in the written test but found that she just memorised the answers. The interviews revealed that Yilmaz "lives in a small world and shows no interest in a dialogue with Switzerland and its population". ${ }^{16}$ Yilmaz did not demonstrate sufficient knowledge of the customs of the region. For example, she could not name Hornussen and Schwingen as typical Swiss sports (she did name skiing), had no close friends in the village, could not specify local cinemas and museums, was unfamiliar with the municipal recycling system, knew little about Easter, and had "un-Swiss" shopping patterns-buying in Aldi, a German chain supermarket. ${ }^{17}$ Reading the interview protocols, one can only wonder who really "lives in a small world"-Yilmaz, or the local councillors in Buchs?

Reading naturalisation cases in Switzerland is entertaining. In 2016, Nancy Holten was denied citizenship for lack of sufficient integration. Holten was born in the Netherlands and has lived in Switzerland since the age of eight. She is married to a Swiss citizen, has two Swiss children, speaks fluent Swiss-German, participates in the social and economic life of the community, respects the values of the Federal and the Cantonal Constitution, and successfully passed a written citizenship test, answering correctly 41 out of 45 questions (91\%). Holten, however, is vegan and a fierce supporter of animal rights. She is against cow wrestling, mouse catching and piglet racing; the supply of cow's milk in schools; livestock farming, the use of animals in a circus, and cowbells, claiming that they are damaging cows' health; and church bells, stating that they are too noisy. The municipality of Gipf-Oberfrick in the Canton of Aargau denied Holten's application, noting that it is unclear why she is publicly "attacking traditions and customs in the village, the region, and the country" and, at the same time, wants to become Swiss. ${ }^{18}$ In the appeal, the Cantonal Executive Council granted her citizenship. The Council rejected the claim that Holten was not integrated into local Swiss traditions and customs; her objections were not against Swiss peculiarities but against common Western traditions. The Council found nothing particularly Swiss in cowbells, church bells and livestock farming-as debates on meat consumption and animal rights are widely shared in Western societies. The Council thereby "universalised" traditions and customs, perceived by the municipality as typically Swiss, and rejected the possibility of excluding a person for lack of integration to these traditions and customs. This conclusion may entail an odd outcome according to which it is acceptable to object to universal traditions, but not to Swiss ones. $^{19}$

Although Swiss citizen-making policies are unique, ${ }^{20}$ becoming a citizen in other European states is a burdensome, sometimes peculiar process. Take Denmark. One path to get a residence permit for work is the Greencard Scheme, which is based on a points system. The migrant must collect at least 100 points on the basis of education level, language skills and adaptability. Another path to get a residence permit is family reunification. A person needs to pass an immigration test (Indvandringsprøven) that consists of two parts: a language proficiency test and a civic exam on

\footnotetext{
${ }^{14}$ See, respectively, questions 2, 54, 58, 63-66, 88, 91, 66, 40-41 in the protocol of the first interview, 'Gesuchsteller Yilmaz', 'Fulden Funda' (20 March 2017) (on file with the author).

${ }^{15}$ Art 5(1), Der Grosse Rat des Kantons Aargau, Gesetzüber das Kantons-und das Gemeindebürgerrecht (KBüG) (12 March 2013).

16‘Einbürgerungsgesuch Fulden Funda Yilmaz, geb.' (3 April 2017); 'Gemelnde Buchs, Gemeinderat Einbürgerungsgesuch, Frau Yilmaz' (25 April 2017) (on file with the author).

${ }^{17}$ See, respectively, questions 61, 36-38, 44, 76-77, 49-50, ibid.; 'Der Fall Funda Yilmaz: Das vollständige Protokoll der Nicht-Einbürgerung', Schweizer Illustrierte (14 July 2017).

${ }^{18}$ E. Roberts, 'Vegan Denied Swiss Citizenship for her “Loud” Views on Animal Rights', CNN (13 January 2017); G. Sassoon, 'Trop énervante Pour Avoir Droit au Passeport Suisse', 24 heures (5 January 2017).

${ }^{19}$ 'Protokoll des Regierungsrats, Sitzung vom 29 Juni 2016, Regierungsratsbeschluss Nr. 2016-000769'; 'Protokoll des Regierungsrats, Sitzungvom 26 April 2017, Regierungsratsbeschluss Nr. 2017-000381' (on file with the author).

${ }^{20}$ For other cases denying citizenship for lack of sufficient integration, see case Ablehnung des Einbürgerungsgesuchs [2015] Nr. A 14166.5, Basel; Case Ablehnung des Einbürgerungsgesuchs [2015] Nr. A 14165.5, Basel; Case Tribunal Fédéral Suisse 1D 6/2014 [2015].
} 
Danish society. ${ }^{21}$ The person must also pass the "housing requirement"; a Danish citizen seeking family reunification should demonstrate that he or she has an adequate residence, owned or co-owned. If rented, the apartment should be of a "reasonable size"-that is, at least 20 square meters per person-and the lease should be permanent or extended. Admission is also subject to the "24-year requirement"; under this rule, both spouses should be older than 24 years. Another demand is the "attachment requirement"; with a few exceptions, both spouses should demonstrate that their aggregate ties to Denmark are stronger than their aggregate ties to any foreign nation. ${ }^{22}$ In order to get a permanent residence permit, a person should have lived in Denmark for at least five years, not receive public support in the three years prior to the application, pass a language test, hold regular employment for at least three out of five years prior to the application, and exhibit active citizenship for one year or pass an "active citizenship" exam (Medborgerskabsprøve). ${ }^{23}$ The applicant should also sign an "Integration Contract" and a "Declaration on Integration and Active Citizenship in Danish society". After passing two tests, required for residence permits, the applicant should pass an additional test to become a citizen ${ }^{24}$-whose success rate is one-third ${ }^{25}$-and should further sign a "Declaration of Awareness" of the rules of Danish citizenship, as well as a "Declaration on Active Participation and Achieving Integration". In addition, foreign children are required to fulfil the legal conditions for family reunification, among them the need to show "integration potential". 26

Citizenship tests are spreading in Europe-most Member States have a test, formal or informal. Spain is perhaps the last country to follow this path. In order to become a citizen, applicants should show "sufficient integration into the Spanish society". ${ }^{27}$ Until October 2015, the law provided local authorities with wide discretion to determine the content and procedure required to assess integration. ${ }^{28}$ There was neither a standard test nor national guidelines of how to prepare for the test. Applicants had to be familiar with Calderon de la Barca (a poet of the Spanish Golden Age), Fernando Alonso (a Formula One racing driver), Rafael Nadal (a tennis player), and Picasso (a painter). Some questions were amusing: "Which river runs between Madrid and Barcelona?" (none!). ${ }^{29}$ The courts were inconsistent on the level of integration sufficient to become Spanish. ${ }^{30}$ In one case, a Nigerian-born citizen, who had resided in Spain since 2000, was denied citizenship. He could not correctly answer questions such as when the Constitution Day is, who Christopher Columbus was, and what the political system in Spain is. The Court considered the fact that he has a work permit and family in Spain, good knowledge of the language, and some knowledge of the society; yet, social and economic integration is not sufficient, according to the Court, if the person cannot also demonstrate "political integration". ${ }^{31}$ In another case, citizenship was denied because the applicant could not specify a good reason for wishing to become a Spanish citizen. ${ }^{32}$ In October 2015, Spain introduced a national citizenship test. The test

\footnotetext{
${ }^{21}$ Aliens (Consolidation) Act, Art 9(12).

${ }^{22}$ See, respectively, arts 9(6), 9(1) and 9(7), ibid.; Case Højesteret DOM 478/2007 B og A mod Ministeriet for Flygtninge, Indvandrere og Integration [2010]; Case Højesteret DOM 248/2009 A mod Ministeriet for Flygtninge, Indvandrere og Integration [2010]; Case Højesteret DOM 253/2010 A mod Ministeriet for Flygtninge, Indvandrere og Integration [2011].

${ }^{23}$ Aliens (Consolidation) Act, Art 11. See also Udlændinge-, Integrations- og Boligministeriet, 'Læremateriale til Medborgerskabsprøven: demokrati og hverdagsliv i Danmark' (Udlændinge-, Integrations- og Boligministeriet, 2016).

${ }^{24}$ Art 24, Tidligere Gældende Cirkulæreskrivelse om Naturalisation (CIS nr. 10873, 13.10.2015).

${ }^{25}$ D. Bilefsky, 'Denmark's Tougher Citizenship Test Stumps Even Its Natives', New York Times (7 July 2016), at https://www.nytimes.com/2016/07/08/ world/europe/denmark-citizenship-test.html.

${ }^{26}$ S. Adamo, 'What is "A Successful Integration"? Family Reunification and the Rights of Children in Denmark' (2016) 1/152 Retfærd. Nordic Journal of Law and Justice, 38.

${ }^{27}$ Art 22.4, Código Civil, Título I.

${ }^{28}$ M.E.C. Cobiella, 'Una Mirada a los Requisitos de la Obtención de laNacionalidad Española por Residencia' (2014) 17 Revista Castellano Manchega de Ciencias Sociales, 229, 236; A.Á. Rodriguez, 'Inmigrantes e Hijos de Inmigrantes Nacidos en España: Vías de Aceddo a la Nacionalidade Española' (2010) 90 Revista del Ministerio de trabajo e Inmigración, 103.

${ }^{29}$ The judgment of Audiencia Nacional SAN 4736/2014 of 21 November 2014, ECLI:ES:AN:2014:4736; J. Garcia, 'Which River Runs between Madrid and Barcelona?' El País (28 November 2014); N. Junquera, 'Aprobaría usted el Test de Españolidade?', El País (11 January 2015).

${ }^{30}$ See, e.g., the judgment of Audiencia Nacional SAN 373/2016 of 20 September 2016, ECLI:ES:AN:2016:3723; the judgment of Audiencia Nacional SAN $3376 / 2018$ of 9 July 2018, ECLI:ES:AN:2018:3376.

${ }^{31}$ The judgment of Audiencia Nacional SAN 4165/2014 of 3 October 2014, ECLI:ES:AN:2014:4165.

${ }^{32}$ The judgment of Audiencia Nacional SAN 2360/2019 of 10 June 2019, ECLI:ES:AN:2019:2360.
} 
contains 25 multiple-choice questions on a variety of topics. The government has also introduced a guide for exam preparation. ${ }^{33}$ In order to become Spanish, one must know that 24 Horas is the TV-channel that broadcasts 24-hour news, Federico Garcia Lorca was a poet, Churros is not a typical sweet for Christmas, and Francisco de Goya was a painter. ${ }^{34}$ The citizenship guide includes different topics, from the legend of Don Juan, through traditional Spanish dances, to the Guggenheim Museum in Bilbao.

Spain is an interesting case for another reason-starting in 2015, Spain has granted citizenship preferences to descendants of formerly exiled Jews, who were forced to leave Spain following the Edict of Expulsion of the Jews (1492). According to the policy, Sephardic Jews do not need to live or work in Spain in order to become citizens. Sufficient is to prove Spanish descent and cultural ties to Spain. "Spanish descent" can be shown by different methods-speaking Ladino, holding a Sephardic surname, and having a certificate from the Federation of Jewish Communities of Spain. A "tie" to Spain is proven by passing a basic language test (level A2) and a citizenship test. ${ }^{35}$ The official justification for the policy is based on compensation for past wrong. This idea is not novel. European states grant visa preferences to people from former colonies. And yet, the Spanish policy, which gives citizenship for historical injustice to descendants of Sephardic Jews, is quite unusual for compensating injustice which occurred in the fifteenth century.

Reviewing European policies indicates four conclusions. First, as states have gradually become "countries of immigration", there is an increasing appeal to citizen-making policies. In 2002, only four out of 14 European states had a compulsory language requirement (29 percent); in 2007, 11 out of 18 states had a compulsory language requirement (61 percent); in 2018, 22 out of 28 European states had a compulsory language requirement (79 percent), including several Member States with a language requirement to be met abroad. ${ }^{36}$ Similarly, a citizenship test, which was largely associated with US law two decades ago, has become common in Europe. In 1999, only four out of 15 EU states had a test (27 percent); in 2018, the number tripled to 17 (61 percent). ${ }^{37}$ Likewise, integration pacts, almost unknown a decade ago, exist nowadays in many Member States, among them Austria, Denmark, France, Germany and the Netherlands. ${ }^{38}$ Residency-the idea that being exposed to certain values and institutions will lead, in and of itself, to a successful integration-is not a sole requirement for becoming a citizen in Member States. Hence, the overall picture is broader than in the above three cases. ${ }^{39}$

Second, citizen-making policies in Europe include a wide range of modes. Some requirements are knowledgebased (language proficiency, civic knowledge), others are behaviour-based (active participation, good character), and others are attachment-based (ethno-cultural affinity, family ties). The means to verify these requirements (knowledge, behaviour, attachment) are also diverse-they vary from citizenship tests, through integration courses, and up to loyalty oaths. ${ }^{40}$ There is a wide disparity in the means and states often apply them differently towards different types of immigrants. Nuances also exist regarding how these means apply, when, towards whom, based

\footnotetext{
${ }^{33 ،}$ CCSE 2019, Manual para la preparación de la prueba de conocimientos constitucionales y socioculturales de España', at https://www.pruebaccse.com/ manual/.

${ }^{34}$ For the official website of the citizenship test, see https://ccse.cervantes.es/.

${ }^{35}$ Ley $12 / 2015$, en materia de concesión de la nacionalidad española a los sefardíes originarios de España.

${ }^{36}$ C. Extramiana and P. Van Avermaet, 'Language Requirements for Adult Migrants in Council of Europe Member States: Report on a Survey' (2011) Council of Europe, 8, 12. Four EU states were not analysed: Bulgaria, Croatia, Portugal and Romania.

${ }^{37}$ S.W. Goodman, 'Naturalisation Policies in Europe: Exploring Patterns of Inclusion and Exclusion' (2010) EUDO Citizenship Observatory, 17 (European University Institute). See also R. van Oers, E. Ersbøll and D. Kostakopoulou (eds.), A Re-definition of Belonging? Language and Integration Tests in Europe (Martinus Nijhoff, 2010). Data for 2018 is based on GLOBALCIT database, mode A06 (ordinary naturalization).

${ }^{38}$ Integration may apply before admission, as a pre-arrival entry. See, e.g., S. Bonjour, 'The Transfer of Pre-departure Integration Requirements for Family Migrants Among Member States of the European Union' (2014) 2 Comparative Migration Studies, 203; K. Groenendijk, 'Pre-departure Integration Strategies in the European Union: Integration or Immigration Policy?' (2011) 13 European Journal of Migration and Law, 1.

${ }^{39}$ For citizen-making policies in other states, see L. Orgad, The Cultural Defense of Nations: A Liberal Theory of Majority Rights (Oxford University Press, 2015), at 87-114 (reviewing Britain, France, Germany and the Netherlands); C. Joppke, 'Through the European Looking Glass: Citizenship Tests in the USA, Australia, and Canada' (2013) 17 Citizenship Studies, 1; I. Michalowski, 'Required to Assimilate? The Content of Citizenship Tests in Five Countries' (2011) 15 Citizenship Studies, 749 (reviewing citizenship tests in Austria, Britain, Germany, the Netherlands and the US).

${ }^{40}$ L. Orgad, 'Liberalism, Allegiance, and Obedience: The Inappropriateness of Loyalty Oaths in a Liberal Democracy' (2014) 27 Canadian Journal of Law and Jurisprudence, 99.
} 
on which format/procedure, under which exceptions, and for what cost. ${ }^{41}$ And, as always, legal formalism does not tell the whole story; local pragmatism often deviates from formal law and, in reality, actual policy may be different.

Third, citizen-making policies are based on national interests and, by and large, do not consider the interests of other Member States or a "European interest", although such decisions affect all Member States and Europe as a whole. States use naturalisation policies as a means to compensate for past injustice, such as the recent law in Spain; overcome the economic crisis, such as citizenship-by-investment schemes in Malta or Cyprus; and prioritise ethnic diaspora outside Europe (Italy, Greece, Hungary, Romania). The disparity in policies in Europe also means that a person wishing to become European can be naturalised in a more permissive state, for instance, Sweden, then resettle in a state with a stricter regime, for instance, Denmark.

Fourth, citizen-making policies remain the competence of Member States and, to a certain degree, reflect the implicit conception of peoplehood in the respective states. If, for example, one considers cultural requirements as repugnant, the critique may be on a society's conception of peoplehood rather than the policy that reflects it. ${ }^{42}$ In other words, the "flaw" may be found not in naturalisation law, but in one's normative perspective of legitimate and illegitimate characters of political communities. In some societies, a person can learn to be a citizen; membership is a function of civic knowledge, political participation and legal obedience (variations of this approach exist in Denmark, Spain and most European states). In other societies, such as Switzerland, one cannot become a citizen by just learning the language and history; becoming a citizen requires showing a high level of societal integration (local adaptation) and accepting certain cultural taboos.

\section{3 | ETHICAL DILEMMAS}

Citizen-making policies raise a wide range of ethical dilemmas. This section focuses on three issues: the motivation for joining a political community, the cultivation of knowledge and the formation of belief, and the legal acceptance of norms. Other factors that influence the ethics of citizen-making policies-their aim, effectiveness, outcome, and theoretical framework-are discussed elsewhere and will not be examined in this section. ${ }^{43}$

\section{1 | Motivation}

Are there proper and improper reasons for joining a political community? Imagine a person attending an interview and stating that he or she wants to become a citizen not for cultural, social or political reasons (e.g., "I love Germany", "I have a family in Spain", "I seek to contribute to the Swiss society"), but purely for self-interest (e.g., "I want to take advantage of the welfare system" or "tax benefits"). Should he or she be granted citizenship?

In Switzerland, Spain and other states, newcomers need to provide a good reason for why they want to become a citizen; otherwise, their application may be denied. In Spain, for instance, an application was rejected because a

\footnotetext{
${ }^{41}$ See, e.g., E. Guild, K. Groenendijk and S. Carrera (eds.), Illiberal Liberal States Immigration, Citizenship and Integration in the EU (Routledge, 2009); C. Joppke and T. Eule, 'Civic Integration in Europe: Continuity Versus Discontinuity', in G. Freeman and N. Mirilovic (eds.), Handbook on Migration and Social Policy (Edward Elgar Publishing, 2016), 343; R. Bauböck and C. Joppke (eds.), How Liberal Are Citizenship Tests? (EUI Working Paper RSCAS 2010/41, European University Institute, 2010); Goodman, above, n. 4, at 42-48; van Oers, Ersbøll and Kostakopoulou, above, n. 37; Michalowski, above, n. 39; Orgad, above, n. 39.

${ }^{42}$ W. Safran, 'Citizenship and Nationality in Democratic Systems: Approaches to Defining and Acquiring Membership in the Political Community' (1997) 18 International Political Science Review, 313.

${ }^{43}$ I examined these functional, empirical and normative considerations in Orgad, above, n. 39, at 159-166; L. Orgad, 'Creating New Americans: The Essence of Americanism under the Citizenship Test' (2011) 47 Houston Law Review, 1227; L. Orgad, 'Naturalization', in A. Shachar, R. Baubock, I. Bloemraad and M. Vink (eds.), The Oxford Handbook of Citizenship (Oxford University Press, 2017), 337. See also B. Byrne, 'Testing Times: The Place of the Citizenship Test in the UK Immigration Regime and New Citizens' Responses to it' (2017) 51 Sociology, 323; S. Goodman and M. Wright, 'Does Mandatory Integration Matter? Effects of Civic Requirements on Immigrant Socio-economic and Political Outcomes' (2015) 41 Journal of Ethnic and Migration Studies, 1885; S. Adamo, 'Northern Exposure: The New Danish Model of Citizenship Test' (2008) 10 International Journal on Multicultural Societies, 10; Guild, Groenendijk, and Carrera, above, n. 41.
} 
candidate did not provide a "sufficient answer" for why he liked Spain. ${ }^{44}$ "Why" questions are popular, but tricky. Most of us faced such questions at some point: "Why do you want to work here?", "Why do you seek to adopt a child?", or "Why do you want to become Jewish?" Nations-like employers, religions and individuals-want to "feel" special and make sure that one seeks to join or unite with them for the "right" reason. This raises a question: should states inquire into one's aim to become a citizen?

Are "Why" questions objectionable? It depends a great deal on their goal. One goal is a communication device for opening a discussion; the same as when a person asks you "is everything ok?", she is usually not expecting a monologue on your personal situation. It is a way of establishing contact. There are other goals. An employee may ask a candidate "Why are you interested in working in this firm?" to evaluate whether the candidate has some knowledge of the firm. The answer can further help to assess the candidate's character or be used for statistical reasons. It may also be that the question is presented to verify that the person has a "genuine link" to the entity she seeks to join. As membership in a political community requires a bond of some kind, a "Why" question is aimed at confirming that a person has acquired, or at least is willing to declare, an attachment to the host society-that he or she is seeking to join a community for intrinsic causes, not merely for instrumental reasons. While these goals (knowledge, statistics, ties) are seen legitimate, one can object to "Why" questions based on illegitimate goals. Such goals exist when the question is used as a means to exclude people, embarrass them, or signal to them that they are unwanted.

Even when the goal is not objectionable, there are good reasons to object to a "Why" question in a citizenship decision. The first reason relates to reliability; studies in cognitive science cast doubt on how trustworthy the answer to a "Why" question is. ${ }^{45}$ People often try to come up with an answer that they perceive as "right", or because they do not trust the judgement of the official. Therefore, the efficiency of such questions is at least doubtful.

A second issue relates to compatibility. In determining a match between a migrant and a political community, naturalisation agents may understand differently one's motivation. A person can specify a reason that is perceived as instrumental (say, welfare stipends) yet, beyond that, there is an intrinsic value-respect for a society that provides social rights and is dedicated to equal opportunities. What one considers instrumental, the other can see intrinsic. In addition, the very idea of a fixed list of "good" reasons is doubtful. Take "buying" citizenship: some people may see it as morally repugnant, while others may value the contribution of each according to his or her ability without a hierarchy between human and financial contribution. Moreover, a person may want to join a society for a "wrong reason" and, nonetheless, the compatibility between the person and the society may be high (think of John who wants to marry Kate for a reason seen by her as "wrong", say money, and yet their actual match may be perfect). It is methodologically wrong to judge compatibility merely based on motivation.

A third issue relates to flexibility: reasons can change, and indeed change, very often. One may want to become Danish for instrumental reasons, and years after can develop a strong tie to the Denmark (regardless, intentions are not "inherited" and second-generation immigrants may feel differently). Likewise, a person may want to become Danish for patriotic reasons yet later become alienated and hostile towards the Danish society. A person's reasons (wishes, needs, aspirations) rely on assumptions that may change over time in the ongoing mutual interaction between an individual and a society.

Given the problematic nature of "Why" questions, should states inquire into one's motivation to become a citizen? One option is to directly ask a "Why" question (Section 2 shows that this option exists in some states). A second option is to avoid asking such a question but taking the answer into account when the information is known because the person voluntary reveals it. A third option is to avoid asking such a question and ignoring the answer even when it is known. Choosing the right option is a dilemma. Even those who object to "Why" questions may still hold that some reasons should not be tolerated-e.g., when a person seeks citizenship to promote fascism-and a society could, and even should, deny a citizenship petition in extreme cases. This is either because some reasons are improper-

\footnotetext{
${ }^{44}$ SAN 2360/2019, above, n. 32; compare to SAN 373/2016, above, n. 30.

${ }^{45}$ P. Dewdney and G. Michell, 'Asking "Why" Questions in the Reference Interview: A Theoretical Justification' (1997) 67 The Library Quarterly Information, Community, Policy, 50.
} 
exclusion is based here on the assumption that certain reasons should not be tolerated per se-or because applicants who are motivated by certain reasons are likely to perform intolerant behaviour; exclusion is based here on a concern of future behaviour that is allegedly derived from a stated motivation.

Motivation inquiries can be perceived differently by different citizenship theories. For communitarians, it may be legitimate to verify that a person who seeks to join a society is committed to the common good, is willing to participate in the public life, and does not seek to undermine social cohesion. For liberals, states should generally not inquire into motivation. People may want to become citizens for various considerations. The reasons ought not to be investigated; when they are known, they should not be decisive in the overall decision. But even liberals may not deny that, in extreme cases, reasons should count (if known) when they indicate a serious threat to the rule of law, core liberal institutions and the peaceful coexistence of society.

\subsection{Knowledge and Belief}

What are the appropriate and inappropriate goals of integration in a liberal democracy? Most liberal theorists agree that the goals should include the transmission of some level of knowledge; citizens must know something about their political community. The type of required knowledge is disputed. Should newcomers be familiar only with a society's basic laws and political institutions, or also know essential social mores and cultural norms? How about history, religious traditions or everyday life-the way "we" do things in society? Whatever the type of knowledge is, how far should a liberal state go in instilling it-is "basic" knowledge enough, or should it be "sufficient" and "adequate" (and what are the real differences between such requirements)? These basic questions are not agreed upon in the context of immigrant integration and, in fact, they are rarely discussed.

One issue relates to integration goals: should it be the cultivation of knowledge, or also the formation of belief and character (states often require newcomers to show good moral character ${ }^{46}$ )? A goal is needed to evaluate the process and optimise its validity, reliability and fairness in terms of content and format. ${ }^{47}$ From a liberal perspective, cultivation of knowledge is seen more legitimate than the formation of belief, although the distinction between the two is not clear-cut. Take the following statements: "My name is Liav Orgad", "Plants produce oxygen", "Eating carrots improves your sight", "The sky is blue". Which one is knowledge and which one is belief? What are the tests of validation, the criteria for deciding, and the sources for truthfulness? The differences between knowledge and belief are important particularly in the case of immigrants, because, due to religious and cultural differences, what one considers "knowledge" another may see as "belief".

The cultivation of knowledge is seen as essential in a liberal democracy for various reasons. One reason is the flourishing of the polity. Teaching knowledge provides newcomers with vital information and encourages their political participation, civic responsibility and sense of belonging. Some shared knowledge, so the argument goes, is essential to the functioning of democratic institutions, governing a welfare state, and living together in a society. A second reason can be moral formation. Teaching knowledge may shape newcomers' attitudes. It can indirectly lead them to accept that some moral propositions are well warranted, even if contestable, and possibly increase their identification with state institutions and to have faith in them.

Knowledge, however, is an elusive concept. ${ }^{48}$ What does it mean to know something? Philosophical accounts of knowledge focus on evidence based on which one believes that a thing can justifiably be called knowledge; there is a rational method of validation. In Plato's dialogue Meno, Socrates holds that knowledge is an evidence-based true

\footnotetext{
46'Promiscuous? Divorced? Eccentric-looking? You May be Denied a Passport', The Economist (5 May 2018) (in 2016, 44\% of all refusals for citizenship applications was due to lack of good character. Reasons for bad character include "drinking, gambling, divorce, promiscuity and 'eccentricity, including beliefs, appearance and lifestyle'").

${ }^{47}$ National Research Council, Committee on the US Naturalization Test Redesign, Redesigning the US Naturalization Tests: Interim Report (The National Academies Press, 2004).

${ }^{48}$ W. Althof and M.W. Berkowitz, 'Moral Education and Character Education: Their Relationship and Roles in Citizenship Education' (2006) 35 Journal of Moral Education, 495; K. Murphy, P. Alexander and K. R. Muis, 'Knowledge and Knowing: The Journey from Philosophy and Psychology to Human Learning' (2012) 1 Educational Psychology Handbook, 189.
} 
belief. There is a true proposition, which one believes in, based on evidence justifying it. ${ }^{49}$ Yet this definition is circular since, unless there are reasons to believe that the proposition is true, it cannot be true, and if it is true, it means that there is good evidence for it. The component of evidence is also central in educational psychology in which "knowledge" is information according to scientific evidence, while "belief" is uncertain information not supported by scientific evidence. ${ }^{50}$ Whatever knowledge is, there is little attempt to bring findings from the field of science education-philosophy of education, educational psychology and epistemology-in order to better understand dilemmas associated with immigrant integration. For instance, understanding the ways newcomers distinguish between knowledge and belief, recognising the different criteria they use to distinguish them, and analysing the reasons immigrants give to justify their choices-can contribute to a more nuanced learning process. ${ }^{51}$

In addition, there should be a clarification of the type of knowledge. Should the focus be history and civics, or also popular culture? Is knowledge merely legal (what is "right"), or also moral (what is "good")? Should the process focus on "known" dogmas and stories? Take question 86 of the US Naturalisation Test: "What major event happened on September 11, 2001, in the United States?" The "right" answer is "Terrorists attacked the United States". Imagine that a person knows the right answer, but adds that she does not believe in this interpretation, or at least has no conclusive evidence to support it. If the migrant is a philosopher, she may cite Nietzsche by saying "there are no truths, only interpretations". If she is a lawyer, she may claim that there is no commonly accepted legal definition of the term "terrorism" in international law. Which migrants should be naturalised-a philosopher-type, a lawyer-type, or a parrot-type, who repeats the words we teach them?

Similarly, what should be the connection between "knowledge" and "sufficient integration"? Denying citizenship to a person who has lived and worked in the society for years, has natural-born children and speaks the local language due to "insufficient integration" merely because he did not know when the Constitution Day is, could not find Catalonia on the map, and was unfamiliar with famous Spanish monuments is absurd. ${ }^{52}$ It gives priority to knowledge-if a memory capability can ever be counted as knowledge-in evaluating when integration has become "sufficient". And it makes knowledge the central test for proving sufficient integration in spite of the existence of alternatives. True, some knowledge can be so fundamental to living together without which one cannot claim to belong; still, the type of this knowledge and the consequences for its absence is less clear-cut.

The desirable concept of knowledge is connected with the ideal concept of "good citizenship". ${ }^{53}$ Not surprisingly, there is no precise answer to the question of who is a "good citizen", as there is no precise answer to the question of who is an ideal lover or employee. In a republic, a citizen should be politically active and promote the common good, while liberals may require legal obedience, at minimum, and a commitment to liberal institutions, at maximum. Minimal conceptions of knowledge run the risk of not being enough to create citizens who have the commitment that is so crucial to the adequate maintenance of a liberal state. Maximal conceptions of knowledge run the risk of endorsing qualities that exceed the principled consensus and setting higher hurdles for newcomers compared to citizens. ${ }^{54}$

Can the goals of immigrant integration also include the formation of certain beliefs? Liberal theory does not exclude that option based on several assumptions. The first assumption is that some beliefs among citizens are essential for the survival and flourishing of liberal democracy, ${ }^{55}$ because "citizens, not courts or legislatures, are

\footnotetext{
${ }^{49}$ D. Sedley (ed.), Plato, Meno and Phaedo 96b-98c, 98c-100c (A. Long trans, Cambridge University Press, 2010).

${ }^{50}$ R. Abelson, 'Differences Between Belief and Knowledge Systems' (1979) 3 Cognitive Science, 355; S.A. Southerland, G.M. Sinatra and M.R. Matthews, 'Belief, Knowledge, and Science Education' (2001) 13 Educational Psychology Review, 325; M.F. Pajares, 'Teachers' Beliefs and Educational Research: Cleaning up a Messy Construct' (1992) 62 Review of Educational Research, 307.

${ }^{51}$ C.A. Chinn and A. Samarapungavan, 'Distinguishing Between Understanding and Belief' (2001) 40 Theory into Practice, 235.

52 Judgment of Audiencia Nacional SAN 4642/2015 of 9 December 2015, ECLI:ES:AN:2015:4642. See also judgment of Audiencia Nacional SAN 2727/2015 of 20 July 2015, ECLI:ES:AN:2015:2727.

${ }^{53}$ T.H. McLaughlin, 'Citizenship, Diversity and Education: A Philosophical Perspective' (1992) 21 Journal of Moral Education, 235 (discussing four elements of good citizenship-identity, virtues, political involvement and social prerequisite).

${ }^{54}$ W. Galston, 'Civic Education in the Liberal State', in N.L. Rosenblum (ed.), Liberalism and the Moral Life (Harvard University Press, 1989), 89.

55J. Rawls, Political Liberalism (Columbia University Press, 1993), at 194-195; Galston, above, n. 54, at 217, $243-244$.
} 
the ultimate custodians of our public morality". ${ }^{56}$ There are thinner and ticker versions of this claim; still, the prevailing wisdom is that democratic knowledge is not sufficient without "democratic dispositions". ${ }^{57}$ The second assumption is that essential beliefs must be taught and encouraged, and not be taken for granted. "Citizens are made, not born", ${ }^{58}$ and there "is no reason to think that the dispositions that characterise good liberal citizens come about naturally". ${ }^{59}$ Liberal states thus need to promote a shared bond based on core liberalism and common civic culture; they should not assume that people living in a liberal state would become good liberal democrats merely by residency and being exposed to liberal values and institution. ${ }^{60}$ The third assumption is that, in promoting liberal values, liberal states should not fundamentally undermine individual autonomy. This is a "catch-22". Liberals want newcomers to have critical thinking-the core of good citizenship-but, in so doing, there is a risk that it would undermine the commitment that is crucial for the survival and flourishing of liberal democracy. Larry Alexander rightly observes that "liberalism appears self-contradictory and incoherent. It must either betray its principles or betray itself (and thereby betray its principles)".61 This liberal dilemma lies at the core of the current debate on immigrant education.

\section{3 | Acceptance}

Can immigration integration go beyond knowledge acquisition and belief formation and further demand acceptance of a society's core values and identities? For liberals, it depends a great deal on what acceptance means.

There are different ways to view acceptance. The first way distinguishes between law and ethics. On the one hand, a person can accept a legal rule or a social norm-say, gender equality-as the law of the land or the dominant social view. Acceptance here means recognising a legal/societal reality. On the other hand, a person can accept the moral validity of a legal rule or a social norm; for example, one accepts gender equality not only as the law or dominant view but also that it is morally good. The second way relates to validity vs interpretation. One can accept the validity of a legal rule or a social norm-acknowledging that gender equality is legally and/or morally valid. At the same time, one can accept the validity of a rule or a norm, as well as a specific interpretation of it; for example, one accepts that gender equality means that men and women equally decide on children's education. ${ }^{62}$ The third way focuses on substance and procedure. A person can accept a substantive rule or a norm, such as gender equality, yet not a certain procedure for the use of power and law-making. For instance, a person can accept gender equality only if its validity and/or interpretation have been decided by consultation with the minority group. The fourth way is related to time and space. A person can accept a rule or a norm "here and now" vis-à-vis always and everywhere-as a future promise to forever accept it. The first meaning is conditional, while the second is eternal. The legitimacy of acceptance depends on how one views it. From a liberal perspective, it is generally more legitimate to require legal rather than moral acceptance, validation of a concept rather than a specific interpretation, procedure rather than substance, and a time-bounded rather than an eternal requirement.

While the legal source for investigating a person's motivation is usually found in an immigration interview, knowledge-in a citizenship test, and character-in providing evidence for a good moral character, ${ }^{63}$ the source for acceptance is often found in the words of loyalty oaths that immigrants are required to declare. The words

\footnotetext{
${ }^{56}$ S. Macedo, Diversity and Distrust: Civic Education in a Multicultural Democracy (Harvard University Press, 2000), at 164-165.

${ }^{57}$ P. White, Civic Virtues and Public Schooling: Educating Citizens for a Democratic Society (Teachers College Press, 1996), at 1; Macedo, above, n. 56 , at 205.

${ }^{58}$ P. Levine, The Future of Democracy: Developing the Next Generation of American Citizens (Tufts University Press, reprint edn, 2015), at xiv.

${ }^{59}$ Macedo, above, n. 56, at 16.

${ }^{60}$ Ibid., at 26-27, 31-36; I. MacMullen, Civics Beyond Critics: Character Education in a Liberal Democracy (Oxford University Press, 2015 ), at 181-212.

${ }^{61}$ L. Alexander, 'Free Speech and "Democratic Persuasion"', in R. Cruft, S. M. Liao and M. Renzo (eds.), Philosophical Foundations of Human Rights (Oxford University Press, 2015), at 379.

${ }^{62}$ Similarly, one can accept the validity of a rule or a norm yet not the authority of a certain body (say, the judiciary) to decide what gender equality means (I leave it open whether accepting the authority of a political body entails accepting its method of interpretation).

${ }^{63}$ While this requirement is often satisfied by showing no criminal record, some states demand more than that. In Britain, an applicant should provide two referees who have known him or her for three years. See Home Office, 'Form AN: Application for Naturalisation as a British Citizen' (2016) 11-12, 19-21.
} 
of the oath vary (not all states have such a requirement although the popularity of oaths is on the rise). The Austrians require immigrants to be a "loyal citizen of the Republic ... conscientiously abide by the laws", and "avoid everything that might harm the interests and the reputation of the Austrian Republic". The French demand adherence to "the principles, values, and symbols of French democracy" and loyalty to "French values". And the British have two oaths: the oath of allegiance requires every immigrant to "be faithful and bear true allegiance to her Majesty Queen Elizabeth the Second", and the loyalty pledge demands to give "loyalty to the United Kingdom ... uphold its democratic values ... [and] observe its laws faithfully". Similar oaths exist outside Europe. In Australia, the immigrants pledge that: "From this time forward, I pledge my loyalty to Australia and its people; whose democratic beliefs I share; whose rights and liberties I respect; and whose laws I will uphold and obey". ${ }^{64}$ The oaths do not always use the word "accept"-common terms are "uphold", "adhere", "endorse" and "sustain"-but the substance is essentially similar.

Another source for verifying acceptance is found in integration contracts that migrants should sign. For instance, to get a permanent residence permit in Denmark, a migrant has to sign a "Declaration on Integration and Active Citizenship in Danish Society". The person must, among other things, "accept that the Danish language and knowledge of the Danish society is the key to a good and active life in Denmark", "accept that men and women have equal obligations and rights in Denmark and that both men and women shall contribute to society", "accept that in Denmark all children shall be given equal respect and self-expression", "accept that Danish society strongly condemns acts of terrorism" and "accept that active commitment to the Danish society is a precondition for citizenship". 65 Before getting citizenship, the person should further sign that he or she accepts becoming self-supporting through gainful employment, understand the fundamental norms and values of the society, and participate in the life of the community. ${ }^{66}$

What does it mean to "accept" the principles, values and symbols of a democracy? If acceptance is taken lightly, a person can easily lie. It is only when words are taken seriously that a dilemma may exist. This was the case for Charles Roach, whose citizenship application was rejected in Canada due to his refusal to pledge allegiance to Queen Elizabeth II. Roach fulfilled all the requirements to become a Canadian citizen, yet refused to pledge allegiance to a monarchy as he believed in a republic form of government and wished to promote a change to the constitutional structure of Canada. The Canadian Court ruled that it is possible to pledge allegiance to the Queen while asking to repeal monarchy. Justice Linden dissented. ${ }^{67}$ In his view, Roach could not actively advocate the abolition of a structure that he accepted; he cannot act to replace monarchy, yet remain loyal to the Queen:

If the oath of loyalty permits one to demonstrate that loyalty to the Crown by advocating its abolition, what is the point of that oath? Is that loyalty or is it disloyalty? Is the oath merely a meaningless formality? Is there any commitment to its content required? ... If all the oath of allegiance achieves is to get someone to promise not to violate the criminal law and to avoid subversive and illegal political methods, something they are already obligated to do, is it of any value?

At the core of the integration debates lie two opposite views-both on how to create good citizens and on the expectations of the naturalisation process. The citizenship envisioned by Aristotle assumes that good citizens should be made. Citing Gorgias, Aristotle explained that "As a mortar is made by a mortar-maker, so a citizen is made by a citizen-maker"; the makers of citizens were the magistrates of the city of Larissa, the Larissa-makers. ${ }^{68}$ State institutions should cultivate good citizenship because citizens, not institutions, are the guardians of the public good. For Immanuel Kant, since humans are not "a nation of angels", but have selfish inclinations, there should be a constitutional design that leads to good citizenship in a way that, on balance, being a good citizen would be self-beneficial.

\footnotetext{
${ }^{64}$ Orgad, above, n. 40, at 100-103.

${ }^{65}$ 'Declaration on Integration and Active Citizenship in Danish Society' (on file with the author).

${ }^{66}$ 'Declaration of Active Participation in Danish Language Learning and Integration into Danish Society' (on file with the author).

${ }^{67}$ Case Roach v. Canada (Minister of State for Multiculturalism and Citizenship) [1994] 2 FC 406 (CA), at para. 56, Linden JA.

${ }^{68}$ Aristotle, above, n. 1, Book III, Ch. II; Aristotle, The Nicomachean Ethics (H. Tredennick ed., J.A.K. Thomson trans., Penguin Classics, 2003), at 118, 5.3.1130b28-29.
} 
Only by good organisation of the state, is a "man forced to be a good citizen". ${ }^{69}$ Hence, a wise constitutional designgood laws and checks and balances-would guarantee good citizenship, not the moral improvement of people (as Noah Webster once said, only "a good constitution, and good laws, make good subjects" ${ }^{\text {") }}$ ). Aristotelian republicanism and Kantian liberalism present two different (yet complementary) approaches required to ensure justice and stability - relying on the virtue of the citizens vis-à-vis institutional design.

Another issue relates to the expectations of the naturalisation process. Under one approach, naturalisation should yield an "average citizen" according to the prevailing norms of good citizenship in a political community. In referring to the standard of good moral character, an American Court once held that it is determined by the settled convictions of a standard person in the society. ${ }^{71}$ Thus, for instance, if most people in a community are lawbreakers, a person should not be denied citizenship in this community for this reason alone. The standard to evaluate requirements such as "good character" and "attachment" to society is not only the written law but also "'the commonly accepted mores': i.e. the generally accepted moral conventions current at the time". ${ }^{72}$ In a similar way, naturalised citizens should not be expected to be more knowledgeable than a standard natural-born citizen. ${ }^{73}$ According to a second approach, the function of naturalisation is not only integration but also selection. Thus, while "we must accept our natural-born citizens as we find them, we can scrupulously select those aliens upon whom to confer the privilege of United States citizenship. More is demanded of an alien than a native-born citizen". ${ }^{74}$ Examining naturalisation policies shows that this approach prevails in the liberal state. They aim at producing an "ideal citizen"-one who is more knowledgeable, skilled and participatory than an average natural-born citizen. Immigrants are expected to show political, economic and cultural contributions to the society, and demonstrate how they can be beneficial. They are expected (and often required) to participate in the political process, strengthen the economy and enrich the cultural diversity of the country, even if these expectations and requirements do not equally apply to natural-born citizens. In short, new citizens are expected to be "super citizens". ${ }^{75}$

Immigrant integration is a multidisciplinary domain in which there are different approaches and competing interests, under different conceptions of citizenship and peoplehood, and for different goals. The ethical dilemmas discussed in this section are just the tip of the iceberg. As the number of people asking to join the European Union increases, Member States (and the EU) will constantly have to deal with them and will need to decide on their position. Should policies be left to the Member States, each according to its interests, or should there also be a normative European framework of some kind (which one, and why)?

\section{I ATTACHMENT AND BELONGING}

The proper policy, wherever it can be pursued, is to keep all citizens alike attached to the constitution.

- Aristotle $^{76}$

The challenge of accommodating a large number of newcomers from different religions and moralities may be new to Europe, but it is not new to the Western world. Many of the contemporary debates in Europe existed in the United States towards Irish Catholics, Jews and Chinese. This section presents one aspect of American naturalisation law that may be valuable to Europe-the requirement that a person is attached to the principles

\footnotetext{
${ }^{69}$ R.J. Sullivan, Immanuel Kant's Moral Theory (Cambridge University Press, 1989), at 241; H. Arendt, Lectures on Kant's Political Philosophy (R. Beiner ed., University of Chicago Press, 1992), at 17.

${ }^{70} \mathrm{~N}$. Webster, 'On Test Laws, Oaths of Allegiance and Abjuration, and Partial Exclusion from Office', in N. Webster, Collection of Essays and Fugitive Writings on Moral, Historical, Political and Literary Subjects (Scholars Facsimiles \& Reprint, 1977), at 151.

${ }^{71}$ In re Hopp [1910], 179 F. 561, 563 (E.D. Wis.).

${ }^{72}$ Case United States v. Francioso [1947] 164 F.2d. 163 (2nd Cir.).

${ }^{73}$ Case Ex Parte Johnson [1901] 79 Miss. 637, 89 Am. St. Rep. 665.

${ }^{74}$ Re Petition of Matz [1969] 296 F.Supp. 927, 930 (E.D. Cal.).

${ }^{75}$ E. Badenhoop, 'Calling for the Super Citizen: Citizenship Ceremonies in the UK and Germany as Techniques of Subject-Formation' (2017) 5 Migration Studies, 409; S. Mazouz, "'Mériter d'être français": Pensée d'État \& expérience de naturalisation' (2008) 40 Agone.

${ }^{76}$ Aristotle, Politics (E. Barker trans., Oxford University Press, 1998), at 240.
} 
of the Constitution. It first explains the historical development of the attachment requirement and its meanings and then indicates lessons for European states. The general claim is two-fold: first, some level of European governance of access to citizenship is required for better protection of both human rights of newcomers and political interests of states. Second, the US attachment framework can guide EU regulation on access to citizenship in a way that takes a stance on the ethical dilemmas discussed in Section 3-although it does not seek to solve these dilemmas in a standard way-and, at the same time, respects the competence of Member States in the domain of citizenship.

\subsection{Attachments to the US Constitution}

In the Naturalization Act of 1795, Congress provided that no person shall be naturalised unless he is "a man of a good moral character, attached to the principles of the Constitution of the United States, and well disposed to the good order and happiness of the same". ${ }^{77}$ The attachment requirement has been intentionally left vague: first, what does "attachment" mean: is it about legal acceptance of a norm, or moral identification with it? Second, what does the "Constitution" mean: is it only the formal document one calls a "constitution", or does it include other legal sources? And third, what are the "principles" of the US Constitution to which a person should be attached?

The attachment requirement was common in the American colonies. Georgia asked newcomers to show "Attachment to the Liberties and Independence of the United States of America" by presenting a certificate, signed by a judge in the previous colony where the person resided. ${ }^{78}$ The certificate had to prove that the person is "a good and worthy citizen" and a "friend to the rights and liberties of America". 79 In Virginia, a person could manifest attachment "by having intermarried with a citizen of this commonwealth or a citizen of any other of the United States". 80 Maryland required "a firm attachment to our government and laws"-which could be fulfilled by words and actions. ${ }^{81}$ After the Declaration of Independence, Congress considered different options and eventually adopted the formula of attachments "to the principles of the constitution of the United States". 82

Reviewing American cases reveals five approaches to the meaning of attachment (these approaches were not consistent and frequently changed). The first approach focuses on knowledge; a person should know something about American history and civics, rights and duties of a citizen, and the US form of government. A person cannot "be attached to principles of which he is entirely ignorant", ${ }^{3}$ or swear allegiance to unknown principles. The second approach focuses on behaviour; a person should possess certain traits-having a good moral character, being law-abiding and participating in the polity. ${ }^{84}$ A person is attached to the Constitution by acting according to its spirit. ${ }^{85}$ The third approach focuses on inner devotion; one should show a positive attitude towards a society's values and institutions and support its essentials. ${ }^{86}$ Civic knowledge and legal obedience are not sufficient if the immigrant cannot

\footnotetext{
${ }^{77}$ Ch. 20, art. 1, 1 Stat. 414, Naturalization Act of 1795.

${ }^{78 ،}$ 'Constitution of Georgia (Rules and Regulations of the Colony of Georgia) (1776)', in H. Dippel (ed.), Constitutions of the World from the Late 18th Century to the Middle of the 19th Century: The Americas Constitutional Documents of the United States of America 1776-1860 (Walter de Gruyter, 2006), at 9; 'An Act for Preventing Improper or Disaffected Persons Emigrating from Other Places, and Becoming Citizens of this State, and for Other Purposes therein Mentioned (August 1782)', in A.D. Candler, The Colonial Records of the State of Georgia (Forgotten Books, 2013), at 162-163.

${ }^{79}$ L.L. Knight, Georgia's Roster of the Revolution (Heritage Books, 2008), at 45-46.

80'Act of 1783-An Act for Admission of Emigrants and Declaring their Rights to Citizenship (1783)', in W.W. Hening (ed.), The Statutes at Large: Being a Collection of All the Laws of Virginia (1823), at 323.

${ }^{81}$ 'An Act for the Relief of Certain Foreigners who have Settled Within this State, and for Other Purposes, Supplemental to the Act of Naturalization (November 1789)', in W. Kilty (ed.), The Laws of Maryland: 1785-1799 (1800); Constitution of Maryland (1776), at https://avalon.law.yale.edu/17th_century/ma02. asp.

${ }^{82}$ F.G. Franklin, The Legislative History of Naturalization in the United States from the Revolutionary War to 1861 (University of Chicago Press, 1906$)$, at 52.

${ }^{83}$ In re Meakins [1908] 164 F. 334, 335 (E.D. Wash.).

${ }^{84}$ Case Luria v. United States [1913] 231 U.S. 9, 23.

${ }^{85}$ Re Rodriguez [1897], 81 F. 337, 338, 355 (W.D. Tex.); Re Pisciattano, 308 F. Supp. 818 (D. Conn. 1970).

${ }^{86}$ Re Shanin [1922] 278 F. 739, 740 (D. Mass.); In re Saralieff [1932] 59 F.2d. 436, 436-437 (E.D. Mo.); Re Siem [1922] 284 F. 868 (D. Mont.); Case Allan v. United States [1940] 115 F.2d. 804.
} 
present affection towards the fundamental principles of the Constitution. ${ }^{87}$ The fourth approach focuses on language proficiency; a person is attached to the Constitution when s/he possesses some knowledge of the society's common language(s). Thus, a person cannot be "said to be sufficiently attached to the principles of a written document which he cannot read". ${ }^{88}$ The fifth approach relates to residency in a society. According to Benjamin Franklin, "When foreigners after looking about for some other country in which they can obtain more happiness, give preference to ours it is a proof of attachment which ought to excite our confidence and affection".89

What are the constitutional principles to which one should be attached to become a citizen? Americans courts have been reluctant to precisely define the essence of the attachment requirement; it has been left as an elastic term that has been invoked according to public policy. Narrow approaches entail that a migrant should be mainly attached to law and order-a peaceful legal change according to the constitutional amendment procedure (Article V). ${ }^{90}$ However, case-law reveals broader approaches, as well. One court ruled that attachments mean "acceptance of the fundamental political habits and attitudes which prevail in the United States". ${ }^{91}$ Similarly, in a rare statement, the District Court of Missouri detailed the US constitutional essentials: ${ }^{92}$

What are the principles of the Constitution? They are in the main: (1) A representative government, as distinguished from a democracy; that is, representative of all groups of citizens as distinguished from any particular class. (2) A dual form of government, as distinguished from a single sovereign with the all-pervading authority therein inherent ... (3) The distribution of governmental authority ... [and (4)] the right of life, liberty, and private property ... [and] due process of law ... These are the political conceptions to which an applicant for citizenship must establish that ... he has been "attached".

Old cases indicate that attachment should be to the general political philosophy of the Constitution. Political changes are tolerated-a person can seek to amend the Constitution and still be attached to it-inasmuch as there is no hostility to fundamental principles or an attempt to "establish an entirely different form of government" or abolish the Constitution's basic structure. ${ }^{93}$ Currently, the US attachment requirement is satisfied by taking the oath of allegiance and filling out a declaration form to bear arms on behalf of the United States and perform work of national importance, if required by law.

\section{2 | Towards a European Citizenship Law?}

The attachment requirement is essentially a plea to establish effective links between a newcomer and a state, a call for jus nexi, as termed by Ayelet Shachar. ${ }^{94}$ International law recognises it. In 1955, the International Court of Justice (ICJ) ruled that citizenship is "a legal bond having as its basis a social fact of attachment, a genuine connection of existence, interests and sentiments". 95 This ruling, known as the "genuine link doctrine", sustained the idea that a state can demand some links/ties before admitting a person to citizenship. These links should be "real and effective". There is no fixed list and links can vary: "the habitual residence of the individual concerned is an important factor, but there are other factors such as the centre of his interests, his family ties, his participation in public life, attachment shown by

\footnotetext{
${ }^{87}$ This approach was overruled in the 1940s. See Case Schneiderman v. United States [1943] 320 U.S. 118, 122; Case United States v. Rossler [1944] 144 F.2d. 463,465 . The Schneiderman case ended the actual investigation into whether a person believes in the Constitution. Immigration officers do not secondguess today a formal acceptance of the US Constitution demonstrated by reciting the oath of allegiance and filling out a form.

${ }^{88}$ In re Katz [1927] 21 F.2d. 867, 867-868 (E.D. Mich.).

${ }^{89}$ J. Madison, The Debates in the Federal Convention of 1787 (Prometheus Books, 2006), at 368.

${ }^{90}$ Case United States v. Schwimmer [1929] 279 U.S. 644, 654, 49 S. Ct. 448, 451, 73 L. Ed. 889.

${ }^{91}$ Petition of Edward Vieth Sittler to be Admitted to Become a Citizen of the United States of America [1961], 197 F.Supp. 278. See also Case Baumgartner v. United States [1944] 322 U.S. 665, 673, 64 S. Ct. 1240, 1244, 88 L. Ed. 1525; Ramadass Naturalization Petition [1971] 445 Pa. 86.

${ }^{92}$ Saralieff, above, n. 86 , at 436 .

${ }^{93}$ Ibid., at 437 (n. 125); Petition of Sittler, above, n. 91; Ramadass, above, n. 91.

${ }^{94}$ A. Shachar, The Birthright Lottery: Citizenship and Global Inequality (Harvard University Press, 2009), at 164-189.

${ }^{95}$ Nottebohm Case Liechtenstein v. Guatemala [1955] I.C.J. Rep. 1955, at 23.
} 
him for a given country and inculcated in his children, etc". ${ }^{96}$ Based on this doctrine, in 1984, the Inter-American Court of Human Rights approved the requirements of language proficiency and civic knowledge as legitimate means to establish an "effective connection with the national community". 97

What role should the EU play in framing the rules and procedures determining who can become a European citizen and under what integration measures? Thus far, the Union has largely managed to avoid these issues. This is not surprising. The basic premise, which is still a good law, is that "international law leaves it to each State to lay down the rules governing the grant of its own nationality", ${ }^{98}$ subject to a few exceptions, such as rights of children, the prohibition of racial discrimination and stateless persons. Nationality law, as Peter Spiro observes, is "the last bastion in the citadel of sovereignty".99

Member States can generally decide who belongs under their conditions. European law leaves naturalisation decisions to the states and allows them to require immigrants to learn the language, history and civics of the host society as a prerequisite for residency and citizenship; and yet, it provides no guidance on the dilemmas discussed in Section 3. The Treaty of Lisbon specifies that the Union may establish measures to support integration, ${ }^{100}$ but it leaves open the issue of permissible and impermissible measures. ${ }^{101}$ And yet, Europe has slightly deviated from the prevailing international law. First, national courts and the European Court of Human Rights have ruled that naturalisation decisions should respect, among other things, rights to privacy and family life and the principle of proportionality. Hence, some goals, such as facilitating integration, are permissible, yet others, such as filtering out people based on indirect ethnic considerations ${ }^{102}$ or birth certificate, ${ }^{103}$ are impermissible. Second, in 2000, the European Convention on Nationality (1997) came into force; it grants states a wide discretion to regulate naturalisation yet provides that the residency requirement should not exceed ten years. And third, soft law includes some guidelines on integration. Examples are the Action Plan on the Integration of Third Country Nationals, the Common Basic Principles for Immigrant Integration Policy, the European Pact on Immigration and Asylum, and the European Handbooks on Integration ${ }^{104}$ Hence, connecting the dots, one may argue that Europe already has some sort of "citizenship law", at least informally.

The Europeanisation of access to citizenship can bring two advantages. At first, human rights law: some European regimes can prevent part of the mistreatment of resident aliens and abuse of power in citizenship allocation. And second, state interests: with the growing number of people asking for European citizenship, it may be in the interest of states to have some guidance on how to legitimately restrict access to citizenship. More important, citizen-making policies are based on national interests and do not consider the interests of other states (or a European interest). Finally, the legal lacuna created by not having EU law is often filled out by national and European courts in a way that is perceived as running against the national interests of states. Thus, some form of EU citizenship law is not only a matter of human rights and ethics but also a matter of political interests of states.

\footnotetext{
${ }^{96}$ Ibid., at 22.

${ }^{97}$ 'Proposed Amendments to the Naturalization Provisions of the Constitution of Costa Rica', Advisory Opinion OC-4/84 [1984] Inter-Am. Ct.H.R. Series A no. 4 , at para. 24. The Court noted that citizenship is a "voluntary act aimed at establishing a relationship with a given political society, its culture, its way of life and its values" (at para. 35).

${ }^{98}$ Nottebohm, above, n. 95, at 23. Compare to art. 1, Convention on Certain Questions Relating to the Conflict of Nationality Laws (12 April 1930), 179 L.N. T.S. 89. See also K. Hailbronner, 'Nationality in Public International Law and European Law', in R. Bauböck, E. Ersbøll, K. Groenendijk and H. Waldrauch (eds.), Acquisition and Loss of Nationality. Volume 1: Comparative Analyses: Policies and Trends in 15 European Countries (Amsterdam University Press, 2006), at 35, 42-45.

${ }^{99}$ P.J. Spiro, 'A New International Law of Citizenship' (2011) 105 American Journal of International Law, $694,746$.

${ }^{100}$ Arts 63a(4), 79(4), Treaty of Lisbon [2007] OJ C306/1.

${ }^{101}$ Compare to arts 7(2) and 17, Council Directive 2003/86/EC of 22 September 2003 on the Right to Family Reunification [2003] OJ L251/12; Arts 5(2), 15 (3), Council Directive 2003/109/ EC of 25 November 2003 on the Status of Third-Country Nationals Who are Long-Term Residents [2003] OJ L16. These Directives allow states to require migrants to comply with integration measures as a prerequisite for entry and residency.

${ }^{102}$ Case 38590/10 Biao v. Denmark, ECLI:CE:ECHR:2014:0325JUD003859010.

${ }^{103}$ Case 53124/09 Genovese v. Malta, ECLI:CE:ECHR:2011:1011JUD005312409.

${ }^{104}$ For the development of EU integration policy, see 'EU Policy Framework for Migrant Integration', at https://ec.europa.eu/migrant-integration/the-euand-integration/framework.
} 
It is too early to predict whether the Union will Europeanise national policies-as was the case, for instance, with the federalisation of citizenship policy in the United States in the nineteenth century-but it is not entirely inconceivable to think of this direction. ${ }^{105}$ A future "EU Citizenship Directive" can determine on three issues: Member States may agree on common rules, regulating areas that will either be a shared core European policy or be left to the sovereign powers (do's and don'ts). For instance, they may agree that "selling citizenship" is impermissible without genuine links to a Member State, or that the means for evaluating integration can vary among states. In other words, states can (1) agree on certain issues, as a minimum; (2) agree to disagree on other issues; and (3) agree on procedures that must be followed on some issues so that a substantive outcome will be respected (even without agreement) if certain procedures are taken. An EU citizenship directive can address fundamental and pressing questions: What core rights must be secured in the integration process? Should integration merely maximise national interests, or should it also contribute to EU interests? What type and level of knowledge and acceptance should be essential for obtaining European citizenship? What should be the meaning of genuine links in the Union? Can a person develop genuine links to the Union through links to different states, which, taken together, may be sufficient for citizenship? To be clear, an EU citizenship directive does not necessarily mean a uniform EU policy, but a partial harmonisation. The European Union can settle core issues and Member States may add requirements, similar to the Swiss model in which the federal law prescribes minimum requirements to which the cantons and the municipalities may add additional requirements based on constitutional locality. In this regard, the Union should become more like Switzerland rather than the United States (in which the domain of naturalisation policy is almost entirely federal). ${ }^{106}$

An intermediate solution, given the difficulty of reaching an agreement among Member States, can be multilateral agreements. Take residency requirements, for example. If Germany requires eight years' residence for ordinary naturalisation, a multilateral agreement between Germany and other Member States (say, Austria and Italy) can recognise the fulfilment of the residency requirement in one of these states inasmuch as the applicant has lived eight years in these states altogether, even if not eight years entirely in one state. Such an idea may, in the long run, politically incentivise other Member States to join the multilateral agreement for their benefit. This approach would enable noncitizens an option to get European citizenship by demonstrating "genuine links" to different Member States, which, although they might not be sufficient for national citizenship in one state, could still grant access to citizenship by showing sufficient aggregated genuine links.

A partial harmonisation of EU citizenship law can retain the competence of Member States to require attachments to their constitutional particularity. Between core requirements that Member States would have to demand, and those requirements that Member States must not impose, each state may add requirements. For example, states can decide whether to give weight to one's motivation and whether to require only "knowledge" of some type or also "acceptance" of particular values and institutions. Every Member State has a constitutional uniqueness reflecting its historical experience, development, tradition and contextual background surrounding its creation-what is often called "constitutional identity"; citizen-making policies can focus on developing attachments to a state's constitutional particularity. ${ }^{107}$ European law seems to uphold such a direction. Article (4) of the Treaty of Lisbon provides that the Union shall respect Member States' "national identities, inherent in their fundamental structures, political and constitutional". ${ }^{108}$

\footnotetext{
${ }^{105}$ For the pros and cons of the Europeanization of citizenship law, see L. Orgad and J. Lepoutre (eds.), Should EU Citizenship Be Disentangled from Member State Nationality? (EUI Working Paper RSCAS 2019/24, European University Institute, 2019). See also a Special Issue, 'EU Citizenship: Twenty Years On' (2014) 15 German Law Journal.

${ }^{106}$ For the federalization of naturalization in the United States, see P. Weil, The Sovereign Citizen: Denaturalization and the Origins of the American Republic (University of Pennsylvania Press, 2013), at 15-52. For the Swiss case, see R. Argast, S. Arlettaz and G. Arlettaz, 'Citoyenneté, nationalité et formation nationale en Suisse (1798-1925)' (2003) 29 Etudes et Sources, 129.

${ }^{107}$ I discussed the connection between naturalization policy and constitutional identity, as well as sources and methods for identifying constitutional identity, in Orgad, above, n.39, at 212-226.

${ }^{108}$ Art 4(2), Treaty of Lisbon, above, n. 100. See also art. 167, Treaty on the Functioning of the European Union [2010] OJ C83/47 (The Union "shall contribute to the flowering of the cultures of the Member States, while respecting their national and regional diversity").
} 


\subsection{Genuine Links to Europe}

The 2019 Report of the European Commission (EC) on citizenship by investment has placed the attachment requirement on the European agenda. The Report favours the development of some genuine links to a Member State as a prerequisite for citizenship, and seems to dismiss the case in which a person is granted citizenship without any prior link:

Since under Article 20 TFEU, citizenship of the Union is an automatic consequence of holding nationality of a Member State and a host Member State cannot limit the rights of naturalised Union citizens on the grounds that they acquired the nationality of another Member State without any link with that awarding Member State, each Member State needs to ensure that nationality is not awarded absent any genuine link to the country or its citizens. ${ }^{109}$

The EC Report, thus, can serve as a starting point to adopt a European attachment framework as a minimum on which states can add additional requirements.

What does it mean to be attached to the principles of a constitution? First, it means attachments to a normative concept, a constitution, not to sociological and anthropological conceptions such as social mores, national identity or societal culture (unless they have been constitutionalised). In general, it excludes items such as cinemas and museums, good grades in schools, or painters and rivers. One challenge relates to the meaning of the term "Constitution". Those who view a constitution as a legal document may focus on text-values, principles and institutions of a formal written constitution. Those who view a constitution more substantively-as a set of fundamental principles and institutions according to which a state is governed-may end up with requirements that go beyond a formal text to notions of basic ways of life. ${ }^{110}$ Similarly, for "living constitutionalists", attachments should be a dynamic document that is open to peaceful amendments. "Static constitutionalists", however, may also require attachments to the timeless constitutional truths of a political community, and be less tolerant to some fundamental changes in them, even if they are promoted according to the amendment procedure (think of laïcité in France).

There are three reasons justifying placement of the constitution as the focus of the attachment requirement. First, it is a legal concept, which is less arbitrary than the notions of social mores, national identity and societal culture. Second, a constitution is presumed to represent the official stance of a political community's essentials, the normative consensus in a given society, as well as the basic structure of the policy (although, admittedly, constitutional identity does not always overlap with social reality). Third, in the Union, the constitutions of Member States are presumed to fulfil the EU criteria of membership (the "Copenhagen criteria"), thereby be in accordance with democracy and the rule of law. So, even if the societal culture of a state may not be democratic, its constitution is assumed to be democratic.

Second, attachment entails a requirement that varies in nature (liberal, communitarian, republican, cosmopolitan), essence (knowledge, acceptance, identification) and method of approval (residency, test, oath, contract)-each state according to its conception of citizenship. ${ }^{111}$ For communitarians, attachments may mean acceptance of constitutional essentials, while for liberals, attachments may be narrower-knowledge of the law, willingness to obey it and legal acceptance of the outcome of just political institutions. For republicans, attachments can further entail participation in the communal public life as manifested, for example, by voting and paying taxes.

Some knowledge of the constitution and some level of acceptance of its essentials are seen as necessary for the survival and flourishing of a liberal state. "The Constitution has but two enemies", observed John Davis, "The first of these is ignorance" of its meaning and of "the great truths on which it is founded", and "the second is indifference-the sort of indifference which leads many people, otherwise well enough behaved, to ignore both the rights

\footnotetext{
${ }^{109}$ 'Investor Citizenship and Residence Schemes in the European Union', (23 January 2019) SWD(2019) 5 final, at 6

${ }^{110}$ U. Volkmann, 'What Does a Constitution Expect from Immigrants?' (2017) 18 German Law Journal, 1641

${ }^{111}$ G.L. Neuman, 'Justifying US Naturalization Policies' (1994) 35 Virginia Journal of International Law, 237.
} 
and duties of citizenship". ${ }^{112}$ These attachments-knowledge and acceptance-can be not only to legal principles but also to a particular legal meaning in society. Hence, an immigrant should demonstrate attachments not only to abstract principles, but also to a particular legal interpretation. This does not solely mean attachments to universal principles such as "all men are created equal", but also to a particular legal understanding of equality in a given society. In this regard, attachments can be thicker in Europe than the current understanding of the US attachment requirement, which is satisfied by taking the oath of allegiance and filling out some form.

Third, attachments to constitutional principles require a reflection on the principles that a migrant should be attached to. Such principles can be the most fundamental values and institutions of a political community, either different interpretations of universal principles (dignity, tolerance, liberty) or particular values and principles. Most European states hold values and principles that are not just different interpretations of universal values, but are rooted in ethnocultural histories, religious heritages and traditions. Notable examples are official languages-a state language is usually a key feature of a society's constitutional identity, whether it is explicitly anchored in the Constitution, as in France and Spain, or not, as in Germany; religious symbols and institutions, including the official or quasi-official status of the Church-as in England, Greece, Italy and Denmark; traditional national institutions, such as monarchy in Britain and Scandinavia; public identities, for instance, national holidays and symbols; and particular constitutional concepts, like the French laïcité. Some of these features are symbolic and have little practical implications; nonetheless, they reflect, to different degrees, normatively and practically, the still-existing constitutional identity.

One advantage of the attachment requirement relates to its functionality. There is no one way to demonstrate attachment. Think of love as an analogy: how should a person demonstrate love? For some, it is a matter of statement, saying "I love you" (one time or as a continuous ritual). For others, a statement may not be sufficient due to the fear that people lie; instead, some patterns of behaviour should be demonstrated (whatever they are). Yet for others, behaviour is insufficient because people can follow patterns of behaviour that allegedly demonstrate love; instead, it is essential to inquire into one's feelings. For others, the mere decision to be together may be the best evidence of love. The rule of attachment functions in a similar way-one can demonstrate attachment by alternative methods: statement, action, membership in associations, marriage and participation in public life.

Another advantage of the attachment requirement is that it is not exclusive. It deviates from dichotomous approaches-the typical approach assumes that there are grounds for inclusion, which must be met, and grounds for exclusion (inadmissibility) that a person should pass-and offers an approach under which no one is excluded or included per se. It gives a person an opportunity to become a citizen if alternative ties are fulfilled. In other words: there are no exclusive grounds for inclusion or inadmissibility. Take residency: under the current approach, if the residency requirement is a minimum of five years, a person who lives in a society four years cannot become a citizen. Under a non-exclusive approach, criteria can be set according to the length of residency-the longer a person resides in a society, the fewer conditions (civic knowledge, language proficiency, etc.) she will be required to fulfil. A person may show attachments through language proficiency, civic knowledge, positive motivation to join the community, family ties, labour ties, cultural affinity or good character-all will be balanced against possible indicators of "bad citizenship" (criminal record, public charge, etc.). Take ethno-cultural affinity. Under the current approach in some states, a person whose ethno-cultural background is similar to that of the majority can, in some countries, get automatic citizenship. Under a non-exclusive approach, a migrant may be able to use an ethno-cultural affinity for showing some attachments, yet will not receive automatic citizenship-s/he will still have to show other links to the country. ${ }^{113}$ From this perspective, integration will not apply equally to all cases; the more links one has, the less stringent integration programmes will be.

\footnotetext{
${ }^{112}$ J.W. Davis, 'What Does the Constitution Mean to You?' (1925) 11 American Bar Association Journal, 442, 442-444.

${ }^{113}$ Advisory Opinion, above, n. 97, at paras 18-19.
} 


\section{5 | CONCLUSIONS}

Questions of membership have not changed much since Aristotle. How should a noncitizen join a political community? Should naturalised citizens be "like us"-as an average citizen in the society-or "better than us", representing an ideal type of citizen? These questions are among the most important political decisions. The controversy between Aristotle, according to which good citizens should be created by moral imposition and character improvement, and Kant, according to which good citizens can be naturally emerged by good laws and institutional design, has remained open to date.

Precisely because EU citizenship derives from national citizenship, one could expect that the Member States would exercise sovereign powers according to mutual solidarity. Political reality, however, is quite the opposite. Member States implement under-inclusive citizenship rules "whereby a person has a legitimate claim to EU citizenship status, but does not have it because of illegitimate state practices", ${ }^{114}$ such as denying citizenship based on a "wrong" motivation, or over-inclusive rules whereby persons, who have a less legitimate claim to EU citizenship, still receive it, such as co-ethnics living outside Europe and foreign investors. Individuals and states are trapped in a legal system of different definitions and categories. Sooner or later, Member States may realise that they have a political interest to at least partly harmonise rules for access to citizenship. ${ }^{115}$ The EC Report on investor citizenship is a good start in this direction. $^{116}$

The three integration dilemmas analysed in this article-knowledge acquisition, belief formation and legal acceptance-can guide the future discussion on citizenship acquisition rules in Europe. The article frames the key questions, identifies the normative considerations at stake and suggests a legal framework that can be implemented in Europeaccording to which every newcomer will be required to show attachments to the principles of the constitution of one or more states. The "attachment framework" can potentially serve both human rights law and interests of Member States. Few issues are more pivotal to the future of the Union than its rules of admission.

\section{ORCID}

Liav Orgad (D) https://orcid.org/0000-0001-8491-3955

How to cite this article: Orgad L. The citizen-makers: Ethical dilemmas in immigrant integration. Eur Law J.

2019;1-20. https://doi.org/10.1111/eulj.12338

\footnotetext{
${ }^{114}$ J.T. Arrighi, 'On the Risk of Trying to Kill "Seven at a Blow”', in Orgad and Lepoutre, above, n. 105, at 23-25.

${ }^{115}$ Compare to R. Bauböck, 'If You Want to Make EU Citizenship More Inclusive You Have to Reform Nationality Laws', ibid., at 16 (the "union cannot tolerate either that Member States abuse their exclusive powers to determine their own nationals by arbitrarily depriving nationals of their citizenship, by excluding long-term residents from access to naturalisation, by passing on their citizenship to successive generations born abroad without any tie to their ancestors' country of origin, or by selling it to investors looking for a tax haven ... pooled sovereignty in the EU is not compatible with such wide leeway for states to determine their own nationals since they produce EU citizens that all other Member States must accept not merely as residents and workers but also as participants in the collective self-government of the Union").

${ }^{116}$ Investor Citizenship, above, n. 109, at 8 (n. 45). The EC mentions that "The EU legal migration policy has harmonised the entry and residence conditions of certain categories of third-country nationals and has granted them rights to ensure fair treatment with EU nationals" and, although it does not explicitly call for the adoption of EU citizenship law, it suggests some directions for a "common understanding of the bond of nationality".
} 